Akimov Alexander Olexeyevich, PhD in Public Administration, Associate professor, Honored Economist of Ukraine, head of the legal department, National Mediation and Conciliation Service, 01004, Kyiv, Str. Baseina, 1/2A, tel.: (044) 23545 01, e-mail:1970aaa@ukr.net

ORCID: 0000-0002-9557-2276

Акімов Олександр Олексійович, кандидат наук з державного управління, доцент, заслужений економіст Украйни, начальник відділу правового забезпечення, Національна служба посереднищтва $i$ примирення, 01004, м. Київ, вул. Басейна, буд. 1/2A, тел.: (044) 23545 01, e-mail: 1970aaa@ukr.net

ORCID: 0000-0002-9557-2276

Акимов Александр Алексеевич, кандидат наук по государственному управлению, доцент, заслуженный экономист Украины, начальник отдела правово$2 о$ обеспечения, Начиональная служба посредничества и примирения, 01004, г. Киев, ул. Бассейная, д. 1/2A, тел.: (044) 23545 01, e-mail: 1970аaа@ukr.net

ORCID: 0000-0002-9557-2276

DOI https://doi.org/10.31618vadnd.v1i11.11

\title{
PROFESSIONAL ACTIVITY OF STATE EMPLOYEES OF STATE SERVICE OF UKRAINE ON EMERGENCY SITUATIONS: OPTIMIZATION OF INTERFERENCE RELATIONS OF WORKERS OF EMERGENCY RESCUE DEPARTMENTS WITH SUFFERED
}

Abstract. The article deals with the issues of the activity of civil servants of the State Service of Ukraine for emergency situations, the general concept of interpersonal relations of workers with victims is disclosed, the main aspects of rendering emergency psychological assistance are considered. The ways of perfection of professional optimization of interpersonal relations of workers of rescue units of the DSNC of Ukraine with the victims are analyzed. The analysis and consideration of all existing forms, methods and methods of providing emergency psychological assistance as a single system. For the first time, it is proposed to consider the provision of emergency psychological assistance as a multi-channel queuing system with an unlimited queue. Proposals have been 
made on the activities of government bodies and civil servants to improve the forms, methods and methods of providing emergency psychological assistance to victims in emergency situations. It is noted that for many years, along with the development of psychological ideas, concepts and theories, there was a large "army" of psychologists who worked in health care institutions, in production, in education, in the internal affairs, aviation and space industries, and other sectors of the national economy. The content and results of their activities often did not fall on the pages of newspapers or in scientific publications. But these psychologists and their work often served as the primary source for experimental research and theoretical work of scientists. It is proved that any person, following certain recommendations and having information about the personality characteristics of the victim, will be able to provide him with the first psychological help in certain circumstances. It is very important to know how to help the victim immediately after the tragic event, to master the skills of working with the individual consequences of psycho-traumatic situations. It is especially important to know, in order to identify in a timely manner unfavorable psychological conditions and seek help from a specialist.

Keywords: interpersonal relations, optimization, civil servants, rescue units of the Ukrainian Legislative Council of Ukraine, queuing system, triage, public administration.

\section{ПРОФЕСІЙНА ДІЯЛЬНІСТЬ ДЕРЖАВНИХ СЛУЖБОВЦІВ ДЕРЖАВНОЇ СЛУЖБИ УКРАЇНИ З НАДЗВИЧАЙНИХ СИТУАЦІЙ: ОПТИМІЗАЦІЯ МІЖОСОБИСТІСНИХ СТОСУНКІВ ПРАЦІВНИКІВ АВАРІЙНО-РЯТУВАЛЬНИХ ПІДРОЗДІЛІВ 3 ПОСТРАЖДАЛИМИ}

Анотація. Розглянуто питання діяльності державних службовців Державної служби України з надзвичайних ситуацій, розкрито загальне поняття міжособистісних стосунків працівників з постраждалими, розглянуто основні аспекти надання екстреної психологічної допомоги. Проаналізовано шляхи удосконалення професійної оптимізації міжособистісних стосунків працівників аварійно-рятувальних підрозділів ДСНС України з постраждалими. Проведено розгляд всіх існуючих форм, способів та методів надання екстреної психологічної допомоги як єдиної системи. Відзначено, що упродовж багатьох років разом із розвитком психологічних ідей, концепцій і теорій існувала велика "армія" психологів, які працювали у закладах охорони здоров’я, на виробництві, в освіті, органах внутрішніх справ, авіаційній і космічній промисловості та інших галузях народного господарства. Зміст і результати їх діяльності часто не потрапляли на шпальти газет або у наукові публікації. Але ці психологи та їхня робота часто виступали в якості першоджерела для експериментально-дослідної та теоретичної роботи науковців. Доведено, що будь-яка людина, дотримуючись певних рекомендацій і володіючи інформацією про особистісні особливості потерпілого, зможе за певних обставин надати йому першу психологічну допомогу. Дуже важли- 
вими є знання, як допомогти постраждалим безпосередньо після трагічної події, освоїти навички роботи з окремими наслідками психотравмуючих ситуацій. Це особливо важливо знати для того, щоб вчасно визначити несприятливі психологічні стани й звернутися по допомогу до фахівця.

Уперше запропоновано розглядати надання екстреної психологічної допомоги як багатоканальну систему масового обслуговування з необмеженою чергою. Внесено пропозиції щодо діяльності органів державного управління та державних службовців по удосконаленню форм, способів та методів надання екстреної психологічної допомоги постраждалим у надзвичайних ситуаціях.

Ключові слова: міжособистісні стосунки, оптимізація, державні службовці, аварійно-рятувальні підрозділи ДСНС України, система масового обслуговування, тріаж, державне управління.

\section{ПРОФЕССИОНАЛЬНАЯ ДЕЯТЕЛЬНОСТЬ ГОСУДАРСТВЕННЫХ СЛУЖАЩИХ ГОСУДАРСТВЕННОЙ СЛУЖБЫ УКРАИНЫ ПО ЧРЕЗВЫЧАЙНЫМ СИТУАЦИЯМ: ОПТИМИЗАЦИЯ МЕЖЛИЧНОСТНЫХ ОТНОШЕНИЙ РАБОТНИКОВ АВАРИЙНО-СПАСАТЕЛЬНЫХ ПОДРАЗДЕЛЕНИЙ С ПОСТРАДАВШИМИ}

Аннотация. Рассмотрены вопросы деятельности государственных служащих Государственной службы Украины по чрезвычайным ситуациям, раскрыто общее понятие межличностных отношений работников с пострадавшими, рассмотрены основные аспекты оказания экстренной психологической помощи. Проанализированы пути совершенствования профессиональной оптимизации межличностных отношений работников аварийно-спасательных подразделений ДСНС Украины с пострадавшими. Проведен анализ и рассмотрены все существующие формы, способы и методы оказания экстренной психологической помощи как единой системы. Отмечено, что на протяжении многих лет вместе с развитием психологических идей, концепций и теорий существовала большая “армия” психологов, работавших в учреждениях здравоохранения, на производстве, в образовании, органах внутренних дел, авиационной и космической промышленности и других отраслях народного хозяйства. Содержание и результаты их деятельности часто не попадали на страницы газет или в научные публикации. Но эти психологи и их работа часто выступали в качестве первоисточника для экспериментально-исследовательской и теоретической работы ученых. Доказано, что любой человек, придерживаясь определенных рекомендаций и обладая информацией о личностных особенностях потерпевшего, сможет в определенных обстоятельствах оказать ему первую психологическую помощь. Очень важны знания, как помочь пострадавшим непосредственно после трагического события освоить навыки работы с отдельными последствиями психотравмирующих ситуаций. Это особенно важно знать для того, чтобы вовремя определить неблагоприятные психологические состояния и обратиться за помощью к специалисту. 
Впервые предложено рассматривать оказание экстренной психологической помощи как многоканальную систему массового обслуживания с неограниченной очередью. Внесены предложения по деятельности органов государственного управления и государственных служащих по совершенствованию форм, способов и методов оказания экстренной психологической помощи пострадавшим в чрезвычайных ситуациях.

Ключевые слова: межличностные отношения, оптимизация, государственные служащие, аварийно-спасательные подразделения ГСЧС Украины, система массового обслуживания, триажа, государственное управление.

Problem statement. The growth in the number of extreme situations (man-caused and natural disasters, military conflicts, terrorist acts) in Ukraine in recent years dictates the need for training specialists capable of providing emergency psychological assistance to victims of similar situations.

So, only during the last several years on the territory of our state there have been such resonant emergency situations that have remained forever in the memory of each of us - among them the explosion of ammunition in Novobohdanivka of Zaporozhye region, the crash of Tu-154 plane in Donetsk region, the explosion of household gas in residential house in Dnepropetrovsk in 2006, a flood in the Carpathian region, an accident at the mine. A. F. Zasyadko m. Donetsk 2007, the accident at the mine "Krasnolimanskaya" in the town of Rodinsky 2008, the accident at the mine named after. Karl Marx, Enakievo 2008, state of emergency on the artillery base of the Defense Ministry of Lozovaya, Kharkov region, in 2008, the accident at the mine. A. A. Skochinskogo city of Donetsk, 2009, an accident at the mine them. CM. Kirov, Makeevka
2009, an explosion in a hospital in the city of Lugansk, 2009, an accident at the Sukhodolskaya-Vostochnaya mine in Krasnodon, Lugansk region, 2011, Bazhanov, Makeevka, 2011 and etc.

Therefore, it is no accident that the psychological protection of the population and the psychological support of the civil protection service acquires one of the priority areas of work in emergency situations, as it helps at the critical moment of the extreme situation to the affected population, the relatives of the deceased, the eyewitnesses of the accident and, in the end, feel support, emotional protection, share the pain of loss, reduce the manifestation of a negative psycho-emotional state and sometimes even prevents the emergence of social tension in society [1].

Consequently, the need to provide quality emergency psychological assistance to affected individuals is incredibly increasing. Modern methods, forms and state of organization of such assistance remain at the level of the last decade, and today it no longer meets the challenges of modernity and does not provide qualitative conditions for qualification assistance meeting Euro- 
pean standards, which determined the relevance of this study.

Analysis of the recent research and publications. In the sphere of public administration and public service, problems of social psychology and professional adaptation, such scientists as N. Afanasyeva, A. Akimov, Yu. Bidylo, I. Krinichnaya, L. Pashko, T. Selyukova, N. Sergienko, G. Leshchenko and others.

Interpersonal relations of workers of rescue units are devoted to work with crisis and extreme psychology of such scientists as: A. V. Timchenko [2; 3], N. V. Onischenko [4], A. G. MalkinaPykh [5], L. A. Rudenko [6], A. A. Gonchar, I. I. Bednyak [7], Yu. A. Glushenko [8], A. A. Kachur [9], A. S. Kostritsch [10], A. S. Kuflyevsky [11], R. M. Tsitsei [12], S. M. Mironets [13], I. P. Krinichnaya [14].

General issues of social psychology, including the crisis conditions of man, are devoted to the work of the team of foreign scientists E. Aronson, T. Wilson, R. Eikert [15].

The psychological aspects of carrying out emergency rescue operations in the liquidation of emergency situations were handled by a team of such authors as: V. P. Sadkovsky, V. G. Avetisyan, Yu. N. Senchikhin, S. V. Kulakov, Yu. A. Kulish, V. V. Trigub [16], M. I. Steblyuk [17], N. Sh. Kremer [18].

So, in the above-mentioned works, some issues of crisis and extreme psychology are considered [2-14], general questions of the state of the human psyche [15], the process of carrying out emergency rescue operations in the liquidation of emergency situations [16, 17], but the questions of the organic systemic combination of all methods, principles and methods of psychological interaction between emergency rescue units of the State Emergency Service remained outside the field of view of researchers.

The purpose of the article - to consider the forms, methods and methods of interpersonal relations of emergency rescue workers of the State Service of Ukraine for emergencies as a system of psychological interaction - "psychologist - employee of the rescue unit of the DSNS - the victim", to propose new approaches in public administration to the provision of emergency psychological assistance to the victims in conditions of emergency and emergency.

The statement of basic materials. In Ukraine, a conceptual solution was developed for the establishment in Ukraine of a system of emergency assistance to the population through a single telephone number "112" in order to determine the strategy for building a single effective system for responding to threats to life and/or human health, unlawful actions, emergency situations and other emergency events (NP), through the introduction of a mechanism for coordinating the actions of all emergency services to the population based on an integrated solution to the problem - the transition from the practice of performing its functions in a departmental th subordination to the complex solution of problems arising in the state of emergency taking into account the requirements of European Union standards. The conceptual decisions define the basic principles and directions for the creation in Ukraine of the 112 system, the basic aspects of 
the structure of the system 112, using available resources and the capabilities of emergency services (ESL) and other services to the population [10].

Analyzing the activities of the Ministry of Emergencies of Ukraine, S. M. Mironets defined the content of their professionally important qualities, to which the author referred psychological, ergonomic, physiological, socio-psychological and engineeringpsychological properties. Psychological qualities include attention, memory, thinking and will. Physiological qualities are responsible for the content and conditions for the performance of professional activities. The author refers to the ergonomic qualities of the state of the central nervous system, resistance to monotony and impulsivity. Sociopsychological qualities include sociability and empathy. The state of the musculoskeletal system and the level of self-control are attributed by the author to engineering and psychological professionally important qualities [13].

Further study of the professional activities of the rescuer of the Ministry of Emergency Situations of Ukraine under stressful conditions allowed V. M. Korolchuk draw a number of important conclusions. In particular, the researcher claims that the high level of stress resistance in rescuers is due to individual psychological properties: pronounced professional motivation, low personal and situational anxiety and high level of emotional-volitional regulation. Among other personal qualities of the rescuer, which contribute to successful professional activity, the scientist distinguishes a low level of aggressiveness, emotional lability and a high level of poise, self-confidence and high self-esteem.

For many years, along with the development of psychological ideas, concepts and theories, there was a large "army" of psychologists working in public health institutions, in production, education, internal affairs, aviation and space industries and also in other branches of the national economy. The content and results of their activities often did not reach the pages of newspapers or scientific publications. But these psychologists and their work often acted as the primary source for the experimental and research and theoretical work of scientists.

The work of the psychologists of the DSNC of Ukraine is aimed exclusively at achieving a humane goal that promotes the development of the personalities of the employees of the DSNC of Ukraine, preserves psychological health, increases the effectiveness of professional activities and provides psychological assistance to the people affected during emergency situations. The provision of emergency psychological assistance to populations affected by emergencies is a function of the DSNC of Ukraine. This direction of work in many ways determined the formation and development of the psychological support service of the DSNC of Ukraine. Since psychologists with psychologic education and qualified qualifications for a practical psychologist are assigned to the position of the psychological support staff of the DSNS of Ukraine, the focus was on the suitability of the research groups to determine the professional skills that provide the psychologist with the DNDS of Ukraine professionally and 
effectively to act in an emergency situation, to provide crisis assistance. Such assistance does not require a detailed psychological analysis of the victim's personality, but requires observation of the signs of the victim's condition (the ability to identify and classify them), the ability to establish contact with the victim, to quickly decide on the way to help, the ability to use available tools, etc. Of course, the ability of the psychologist of the DSNS of Ukraine to effectively professionally act in extreme conditions depends on his own ability to withstand stress su [11].

So, interpersonal relations in groups depend on the people who form them, on how correctly their roles are assigned to the group, and here the qualities of the leader are of great importance. To form a favorable working environment, it is necessary to know the managerial psychology, namely how the groups of people are formed, what factors influence interpersonal relations in the group and how to build the work of people in the group to form a single team. Before considering interpersonal relations in a group, one must have an idea of what groups are in general, for what purpose people unite, what structure the group has, and how it develops. Therefore, organizational behavior can be considered as behavior in a group. Group behavior is a set of actions and external manifestations of the activity of the group as a whole and the individuals interacting within it, as well as small groups.

Order № 148 of the Ministry of Emergency Situations of Ukraine "On the establishment of non-standard mobile emergency psychological help groups of the Ministry of Emergency
Situations" on 27.02.2008. The procedure for creating such groups was determined. Order № 02-4337/74 of the Ministry of Emergency Situations of Ukraine of 03.04.2008 "On the organization of the work of the emergency mobile emergency emergency group of the Ministry of Emergency Situations", which was replaced by the Order of the already updated DNOS of Ukraine 02-2242/764 dated February 18, 2014 "On the organization of the work of freelance mobile groups of emergency psychological assistance "on the basis of which the" Regulations on the organization of work of the mobile emergency group for emergency psychological assistance to the personnel of the units of the Ministry of Emergency Situations and the people affected by the emergency as a result of the emergency situation "were approved. Order № 02-4337/74 of the Ministry of Emergency Situations of Ukraine dated 03.04.2008 issued Order № 2-2242/764 of February 18, 2014 "On the Organization of the Operation of Freelance Mobile Groups of Emergency Psychological Assistance".

In our opinion, all these measures are necessary and correct, but they do not provide a guarantee of the effectiveness of providing emergency psychological assistance to the personnel of the units of the Ukrainian National Drug Control Service and the affected population as a result of an emergency situation. The fact is that the number of these mobile groups is limited, and the number of people who can demand such assistance can significantly exceed the ability of professional groups to provide it qualitatively. 
N. I. Pirogov first introduced in military field surgery and justified the principle of sorting. He defined the work of the "pledged place" - the prototype of the sorting center, and also pointed to the important circumstance: "Without good order and proper administration, there is no benefit from a large number of doctors, and if they are few, most of the wounded will be left without any help".

In our opinion, this principle of triage can be applied to provide emergency psychological assistance. At the same time, we propose to consider this system of rendering emergency psychological assistance as a "multi-channel queuing system with unlimited queue", the main formulas and methods of calculation of which can be applied in the practice of emergency psychological support groups will be briefly described below [18].

So, every employee of an emergency psychological support group can be considered as one channel of a multichannel QS with n-service channels.

The average number of occupied channels $\bar{k}$ is determined by the formula (1):

$$
\bar{k}=\frac{\lambda}{\mu},
$$

where $\lambda-$ is the intensity of the flow of service requests, enters the $\mathrm{SMO} ; \mu-$ intensity of the flow of service.

The average number of applications in the queue, that is, the number of people who still need assistance and is not provided to them, is:

$$
L_{\text {о.ч. }}=\frac{\rho^{n+1} \cdot \rho_{0}}{n \cdot n ! \cdot\left(1-\frac{\rho}{n}\right)^{2}},
$$

where $\rho$ - average number of applications under maintenance; $n$ - intensity of the flow of service.

The average number of applications in the system, that is, the total number of people in need of emergency psychological assistance, is defined as:

$$
L_{\text {сист. }}=L_{\text {оч. }}+\rho,
$$

where $L_{\text {оч. }}-$ the average number of applications in the queue; $\rho$ - average number of applications under maintenance.

The average time of stay of the application in the queue and the average time of the application stay in the system are calculated using the Little formulas.

$$
T_{\text {сист. }}=\frac{1}{\lambda} L_{\text {сист. }},
$$

where $T_{\text {сист. }}-$ the average time for the application to stay in the queue; $\lambda-$ the intensity of the flow of requests for services, goes to the SMO; $L_{\text {сист. }}-$ average number of applications in the system.

$$
T_{\text {оч. }}=\frac{1}{\lambda} L_{\text {оч. }},
$$

where $T_{\text {оч. }}$ - average time of application stay in the system; $\lambda$ - the intensity of the flow of requests for services, goes to the SMO; $L_{\text {оч. }}-$ the average number of applications in the queue.

Thus, we gave the basic formulas for calculating the parameters of a queuing system with an unlimited queue, which in our opinion are permissible and they can be used in planning the activity of emergency psychological assistance groups with the affected population and emergency rescue workers.

In turn, under the interactive component in the structure of the psychological contact between the psycholo- 
gist of the DSNS of Ukraine and the victim, we understand the symbolic designation of the characteristics of those communication components that are associated with the interaction of the specialist of the psychological support service with the object of his professional interest. The notion of "interaction" reveals that side of the psychological contact that records not only the exchange of signs by means of which the behavior of the victim changes with respect to receiving qualified emergency psychological help, but also the organization of joint actions allowing the psychologist, rescue workers of the DSNS and the victims to realize common for them activities in the organization of the disaster. With the correlation of interactive and communicative components of psychological contact (interaction and communication), one can unambiguously determine their unconditional continuity and serving role - the role of tools and communication that can provide interaction (interactive component).

The interaction of a psychologist, an employee of the rescue service of the DSNS and the victim in an emergency situation is characterized by a number of specific signs, features, namely: the existence of a single goal, a common motivation for joint action, unification, combining individual behavior, common conditions, communication to achieve a mutually acceptable result. In the interaction of a psychologist, an employee of the rescue service of the DSNS with the victim in an emergency situation, several typical strategies of behavior towards each other can be identified: facilitating both acting assistance to each other, actively con- tributing to the achievement of common goals of emergency psychological assistance; counteraction of the victim in achieving the goals of establishing psychological contacts and providing emergency psychological assistance, implementing uncoordinated actions that are contrary to the partners in their interaction; evasion from interaction, active care, avoidance of interaction with the psychologist of the DSNN [12].

Rescuing people in an emergency is an important type of emergency rescue and other urgent work, which is a combination of activities to move people from the zone of exposure to dangerous factors of an emergency situation and their secondary manifestations or protect people from these factors, including using individual means protection and protective structures.

Rescue of people in an emergency situation should be carried out using all possible forms, methods and methods, as well as technical means to ensure the greatest safety of both victims and participants in emergency rescue and other urgent work. The order and ways of saving people are determined by the emergency response manager, depending on the situation in the emergency zone and the state of people.

The most complex accidents in terms of carrying out rescue operations can be considered accidents involving the destruction of buildings and structures. The complexity of carrying out rescue work is caused by a large number of affected people trapped in blockages, the need to perform complex engineering work and the threat of further destruction. The experience of carrying out rescue operations on destroyed build- 
ings shows that the necessary amount of forces and resources should be concentrated at the scene of the accident as soon as possible. Since in most cases a person who is in a blockage is able to remain viable for 10 hours [16].

In turn, earthquakes in recent years show that people under the ruins can remain alive, if they are not injured, within two to three weeks. So, in Mexico after the earthquake of 1985, people were found alive under the ruins on the $14^{\text {th }}$ day. In Armenia - in Leninakan, after an earthquake on the fifth day 5398 people were excavated alive, but on the $10^{\text {th }}$ and $11^{\text {th }}$ days they found people alive [17].

When carrying out emergency rescue and other urgent work, the state of the main and emergency escape routes, the technical equipment of the emergency zone, warning systems, emergency lighting, as well as the characteristics of dangerous factors of an emergency situation are taken into account. In the conditions of catastrophes and natural disasters, neuropsychiatric disorders in a significant part of the population are manifested in the range from a state of disadaptation and neuroticity, neurosis-like reactions to reactive psychoses. Their severity depends on many factors: age, gender, level of initial social adaptation; individual characterological features; additional factors at the time of the disaster (loneliness, the presence of dependent children and sick relatives, own helplessness, as well as pregnancy, illness, etc.).

Carrying out psychotherapy and psycho-prophylaxis should be implemented in two ways. The first direction is the elimination of acute panic reactions. Panic is a sense of fear that en- gulfs a group of people, which is then passed on to others and grows into an uncontrollable process. People have a sharp increase in the emotional perception of events that occur around them, their responsibility for their actions decreases. A person can not reasonably assess his behavior, correctly comprehend the real situation. In such an atmosphere, it is enough to express only one thing or express a desire to escape from the area of an emergency, as the human mass begins to blindly imitate it. A person may not understand what is happening or not know what to actually do. When personal security issues are raised, the need for information becomes especially acute, and the behavior of other people is a valuable source of information [15, p. 254].

The second direction - deferred, "delayed" neuropsychiatric disorders. Technical difficulties in conducting rescue operations in disaster zones and natural disasters can lead to the fact that the victims will be in complete isolation from the outside world for a sufficiently long time. In this case, psychotherapeutic help is recommended in the form of emergency "information therapy", the purpose of which is psychological support for the vitality of those who are alive, but is completely isolated from the surrounding world (earthquakes, destruction of houses as a result of accidents, explosions, etc.).

We are sure that any person, adhering to certain recommendations and having information about the personal characteristics of the victim, will be able to give him first psychological help in certain circumstances. Very important knowledge is how to help the victims directly after a tragic event, to master 
the skills of working with the individual consequences of psycho-traumatic situations. This is especially important to know, in order to identify in time unfavorable psychological conditions and seek help from a specialist [1].

"Information therapy" is implemented through a system of sound amplifiers and consists of the translation of the following recommendations that the victims should hear, namely: 1) information that assistance to them is moving quickly; 2) information on the preservation of tranquility as the main means to save them; 3) self-help information; 4) information on the restriction physical efforts of self-evacuation, which can lead to dangerous for them displacement of landslides; 5 ) you should save your energy as much as possible; 6 ) be with your eyes closed, which will bring you closer to a state of easy drowsiness and greater saving of physical forces, etc.

The purpose of "information therapy" is also to reduce the fear of the victims, since the state of a person in an extreme situation is largely determined by the emotion of fear, which up to certain limits can be considered physiologically normal, since this feeling contributes to the emergency mobilization of the physical and mental state necessary for self-preservation.

In addition, as we already mentioned above - the need for information becomes very acute when it comes to personal safety. And here the role of workers who provide emergency psychological assistance as a "reliable" and "authoritative" source of information is very large. If you lose critical attitude to your own fear, reduce and disappear the opportunity to control your actions and make logically based decisions, various disorders (reactive psychoses, affective-shock reactions) and panic state are formed.

Depending on the nature of the threat of intensity and specificity of experience, fear varies in a fairly wide range of shades: fear, fear, fear, horror. The main signs of fear include: muscle tension (especially facial muscles) strong palpitation; accelerated shallow breathing; reduced control over one's own behavior.

The perception of space changes, the distance between objects, their size and shape is distorted. The surrounding time seems to be "unreal", and this sensation persists for several hours after exposure. Long-term can be kinesthetic illusions (sensation of the rocking earth, flight, swimming, etc.). When fears are reacted, consciousness is narrowed, the person is in poor control, although in most cases accessibility under external influences, selectivity of behavior, the ability to independently find a way out of the predicament remain [19].

Therefore, relying on the above, it should be emphasized that, interpersonal relations in groups depend on many factors and can develop in different ways. There are several types of relationships in the group, the most preferable of them are the team. The head of the civil servant, both employees and a psychologist, should work on the creation of the team, because the team will not be a team if its members are not interested in achieving the goal, do not show initiative in successfully carrying out the work.

Conclusions. So, the calculations of the probable number of victims and 
the capacity of the SMO can show that the number of personnel of the groups of emergency psychological assistance created by the relevant orders may not be enough to provide assistance to all the victims and needy, therefore it is necessary to create a reserve of emergency psychological assistance groups from among the employees of the relevant medical institutions Ministry of Health of Ukraine, by creating joint normative acts with the DNS of Ukraine, which will be established Lebanon procedures and rules to attract these workers in the groups for emergency psychological assistance, as well as to establish the rules and to give guidelines on the interaction of all participants in the group emergency psychological assistance.

Thus, it is necessary: a) to apply the forms, methods and methods of interpersonal relations of the emergency services of the State Service of Ukraine for emergencies as a system of psychological interaction - "psychologist - employee of the rescue unit of the DSNS - the victim" using a multichannel queuing system and unlimited queue; b) make a number of changes to regulations; c) central authorities that implement policies in the field of manmade security, civil protection, and disaster medicine need to work more closely together.

\section{REFERENCES}

1. Medical Sorting, (2017), [Electronic resource]. - Access mode: http://locus23.narod.ru/triage1.htm - Name from the screen. Providing emergency psychological assistance to the affected population as a result of an emergency.
2. Timchenko A. V. (2007), Extreme psychology: a textbook. - Kharkov: UTSUZ. $-502 \mathrm{p}$.

3. Timchenko A. V. (2010), Crisis psychology: Textbook. - Kharkov: NUTSUZ, KP "City Printing House". - 383 p.

4. Onischenko N. V. (2011), "The main problems of organizing emergency psychological assistance to victims in emergency situations". Problems of extreme and crisis psychology. Collection of scientific papers. Vip. 10. Kharkov: NUTSUZ. - 268 p.

5. Malkin-Pykh A. G. (2005), Psychological help in crisis situations. - M.: Eksmo Publishing House, 960 p. (Handbook of a practical psychologist).

6. Rudenko L. A. (2014), "Interpersonal relations as a factor of social formation of the individual" [Electronic resource]. - Access mode: http://lib. iitta.gov.ua/7600/1/Ст\%20УКУ.pdf

7. Gonchar A. A., and Bednyak I. I. (2015), "The problem of formation of professional communication skills of future civil protection specialists in the conditions of the university of the DSNS of Ukraine", Materials of the all-Ukrainian scientific and practical conference of cadets and students [Actual problems of technical and socioactivities of the Civil Protection Service]. - April 8. - P. 141.

8. Glushenko Y.A. (2015), "Psychological prerequisites for preventing conflicts in the professional activities of workers in firefighting and rescue units", Materials of the all-Ukrainian scientific and practical conference of cadets and students [Actual problems of technical and social sciences and humanities in the provision of civil protection services]. - April 8. - P. 131.

9. Kachur A. A. (2015), "To the issue of psychological rehabilitation of rescuers of the DSNC of Ukraine and their families", Materials of the all-Ukrai- 
nian scientific and practical conference of cadets and students, [Actual problems of technical and social sciences and humanities in the provision of civil protection services]. April 8. - P. 169.

10. Kostritsch A. S. (2015), "Conceptual solutions for the creation of an automated system for emergency assistance to the population by a single telephone number "112", Materials of the allUkrainian scientific and practical conference of cadets and students, [Actual problems of technical and social and humanitarian sciences in the provision of civil protection services]. April 8. - P. 173.

11. Kuflyersky A. S. (2016), "Professiographic analysis of the activities of employees of the psychological support service of the State Service of Ukraine for Emergencies", [monograph]. Moscow: HNADU. - P. 136.

12. Tsycei R. M. (2014), "Interactive component in the structure of the psychological contact of the psychologist of the DSNS with the victim in an emergency situation”, Access mode: http: //nuczu.edu.ua/sciencearchive/ProblemsOf ExtremeAndCrisisPsychology/vol14_1/Pekp_2013_14(1)_42. pdf

13. Mironets S. M. (2007), "Negative mental states and reactions of workers of emergency rescue units of the Ministry of Emergencies of Ukraine in emergency situations", Abstract of Ph.D. dissertation psycho, University of Civil Protection of Ukraine, Kharkov, 250 liters. - Access mode: http:// www.disslib.org/nehatyvni-psykhichni-stany-ta-reaktsiyi-pratsivnykivavariyno-rjatuvalnykh-pidrozdiliv. html

14. Krynychna I. P. and Akimov O. O. (2016), "Impact of externaland internal factors on formation of psychological preparedness for own activity of pub- lic servants" [Electronic resource]. Access mode: http://ep3.nuwm.edu. ua $/ 5951 / 1 / \%$ D0\%90\%D0\%BA\%

15. Aronson E., Wilson T., and Aikert R. (2002), Social psychology. Psychological laws of human behavior in society. - St. Petersburg: PRIME-EVROZNAK. $-560 \mathrm{p}$.

16. Sadkovogo V.P. Avetisyan V. G. Senchikhin Yu. N., Kulakov S. V. Kulish Yu. A. and Trigub V. V. (2006), Emergency and rescue work: A textbook. Kyiv. -453 p.

17. Steblyuk M. I (2007), Civil Defense and Civil Protection: A Textbook. M .: Knowledge-Press. - 487 c.

18. Kremer N. Sh., Putko B. A., Trishin I. M. and Fridman M. N. (2003), Investigation of operations in the economy: Textbook for universities. - Moscow: UNITY. - 404 p.

19. Studopedia, (2013), "The influence of group dynamics on the stability of the collective" [Electronic resource] Access mode: http://studopedia. su/4_39854_vpliv-grupovoi-dinamik̄i-na-stabilnist-kolektivu. html

\section{СПИСОК ВИКОРИСТАНИХ ДЖЕРЕЛ}

1. Медищинская сортировка [Электронный ресурс]. - Режим доступа: http://locus23.narod.ru/triage1. htm - Назва з екрану. Надання екстреної психологічної допомоги постраждалому населенню внаслідок надзвичайної ситуації.

2. Екстремальна психологія: підручник / за заг. ред. проф. О. В. Тімченка. - Х. : УЦЗУ, 2007. - 502 с.

3. Кризова психологія: навч. посіб. / за заг. ред. проф. О. В. Тімченка. Х.: НУЦЗУ, КП “Міська друкарня”, 2010. - 383 c.

4. Онищенко Н. В. Основні проблеми організації надання екстреної психо- 
логічної допомоги постраждалим в умовах надзвичайної ситуації. Проблеми екстремальної та кризової психології: зб. наук. пр. - Вип. 10. Харків: НУЦЗУ, 2011. - 268 с.

5. Малкина-Пьх А. Г. Психологическая помощь в кризисних ситуациях. - М.: Изд-во Эксмо, 2005. 960 с. - (Справочник практического психолога).

6. Руденко Л. А. Міжособистісні стосунки як чинник соціального становлення особистості [Електронний pecypc]. - Режим доступу: http:// lib.iitta.gov.ua/7600/1/Ст\%20УКУ. pdf

7. Гончар О. А., Бідняк I. I. Проблема формування умінь професійного спілкування майбутніх фахівців цивільного захисту в умовах ВНЗ ДСНС України / О. А. Гончар, I. I. Бідняк // Матеріали всеукраїнської наук.-практ. конф. курсантів та студентів “Актуальні проблеми технічних та соціально-гуманітарних наук у забезпеченні діяльності служби цивільного захисту" -8 квітня 2015 p. - C. 141.

8. Глушенко Ю. О. Психологічні передумови попередження конфліктів у професійній діяльності працівників пожежно-рятувальних підрозділів / Ю. О. Глушенко // Матеріали всеукраїнської наук.-практ. конф. курсантів та студентів “Актуальні проблеми технічних та соціально-гуманітарних наук у забезпеченні діяльності служби цивільного захисту" -8 квітня 2015 p. - C. 131.

9. Качур А. А. До питання психологічної реабілітації рятувальників ДСНС України та їх сімей / А. А. Качур // Матеріали всеукраїнської наук.-практ. конф. курсантів та студентів “Актуальні проблеми технічних та соціально-гуманітарних наук у забезпеченні діяльності служби цивільного захисту" - 8 квітня 2015 p. - C. 169.

10. Кострич А. С. Концептуальні рішення щодо створення автоматизованої системи екстреної допомоги населенню за єдиним телефонним номером “112” / А. С. Кострич // Матеріали всеукраїнської наук.-практ. конф. курсантів та студентів “Актуальні проблеми технічних та соціально-гуманітарних наук у забезпеченні діяльності служби цивільного захисту" - 8 квітня 2015 р. - С. 173.

11. Куфлієвський А. С. Професіографічний аналіз діяльності працівників служби психологічного забезпечення Державної служби України з надзвичайних ситуацій: монографія / А. С. Куфлієвський, Ю. І. Середа. Х.: ХНАДУ, 2016. - 136 с.

12. Цицей P. М. Інтерактивний компонент у структурі психологічного контакту психолога ДСНС із постраждалим в умовах надзвичайної ситуації [Електронний ресурс]. Режим доступу: http://nuczu.edu. ua/sciencearchive/ProblemsOfExtr emeAndCrisisPsychology/vol14_1/ Pekp_2013_14(1)_42.pdf

13. Миронець C. M. Негативні психічні стани та реакції працівників аварійно-рятувальних підрозділів МНС України в умовах надзвичайної ситуації: дис. ... канд. психол. наук: спец. 19.00.09 [Електронний ресурс] / Ун-т цивільного захисту України. - Х., 2007. - 250 с. - Peжим доступу: http://www.disslib. org/nehatyvni-psykhichni-stanyta-reaktsiyi-pratsivnykiv-avariynorjatuvalnykh-pidrozdiliv.html

14. Krynychna I. P., Akimov O. O. Impact of external and internal factors on formation of psychological preparedness for own activity of public servants [Electronic resource]. Режим доступу: http://ep3.nuwm. edu.ua/5951/1/\%D0\%90\%D0\% 
15. Аронсон Э., Уилсон Т., Эйкерт Р. Социальная психология. Психологические законы поведения человека в социуме. - СПб.: ПРАЙМЕВРОЗНАК, 2002. - 560 c.

16. Організація аварійно-рятувальних робіт: підручник; за заг. ред. В. П. Садкового / В. Г. Аветисян, Ю. М. Сенчихін, С. В. Кулаков та ін. - Київ, 2006. - 453 с.

17. Стеблюк М. I. Цивільна оборона та цивільний захист : підручник. - К.: Знання-Прес, 2007. - 487 с.
18. Исследование операций в экономике: учеб. пособие / Н. Ш. Кремер, Б. А. Путко, И. М. Тришин, М. Н. Фридман; под. ред. проф. Н. Ш. Кремера. - М.: ЮНИТИ, 2003. - 404 c.

19. Вплив групової динаміки на стабільність колективу [Електронний ресурс]. - Режим доступу: http://studopedia.su/4_39854 vpliv-grupovoi-dinamikina - s t a bilnist-kolektivu. html 